\title{
The Implications of Labour Productivity and Labour Costs on the South African Economy
}

\author{
Itumeleng Pleasure Mongale*
}

\author{
School of Economics and Management, University of Limpopo, South Africa
}

\begin{abstract}
The research has shown that labour productivity growth has been slowing down. This trend is suggesting that the gains in the quality of employment in several regions of the world might be difficult to sustain. Furthermore, the South African workers were found to have the greatest amount of unproductive time and they are said to be having one of the lowest employee productivity stats in the world. The purpose of this study was to investigate the implications of labour productivity and labour costs on the South African economy. The Ordinary Least Square (OLS) based Autoregressive Distributed Lag (ARDL) approach was employed to analyse the quarterly time series data from 1998 to 2018 . Since South Africa is faced with several challenges such as high levels of unemployment, higher wage bills and high levels of poverty; this study is envisaged to provide an empirical evidence to policymakers and union leaders alike to begin to recognise more fully the importance of labour productivity and labour costs towards economic growth. The results indicate that labour productivity has a significant positive impact on economic growth however labour costs have a significant negative impact on the economy of South Africa. Policy formulation should focus on policies that can help to improve the quality of the labour force in order to achieve desired economic growth levels that can help to increase the levels of employment and the reduction of poverty. Similarly, both the workers and the labour unions should be cautious not to milk the cash cow until it dies.
\end{abstract}

Keywords: Labour productivity, Manufacturing, Economic growth, Autoregressive Distributed Lag, South Africa.

\section{INTRODUCTION}

The research has shown that labour productivity growth has been slowing down and this has proven to be a major concern for several countries. Recently, Totaro (2019) indicated that the European Commission issued a sharp warning on Italy, saying the country's massive public debt and long-lasting productivity weakness are posing risks for other countries in the region. The concern is that these dynamics suggest risks with cross-border relevance, in the context of a still-high level of non-performing loans and high unemployment in the region (Totaro 2019).

This trend is suggesting that the gains in the quality of employment in several regions of the world might be difficult to sustain. Even if there are divergences in the economic literature about the impact of productivity on economic growth, it is still regarded as one of the most important drivers of development. The dichotomy about the effects of productivity on growth is led by authors such as Krugman (1994), Rao and Owyong (1997), Hsieh (1999) and Nakamura et al., (2018). Krugman (1994) and Young (1995) argued that the Asian economic miracle is largely attributable to an increase in the quantity and not the quality of the factors of production. They argue that the economic miracle of the Asian economies can predominantly be attributed

\footnotetext{
${ }^{*}$ Address correspondence to this author at the School of Economics and Management, University of Limpopo, South Africa;

E-mail: itumeleng.mongale@ul.ac.za

JEL Classification: C22; C54; J24; O47.
}

to mobilising resources which were mainly done by increasing inputs of machinery, infrastructure and education. In support of Krugman's notion, Felipe and McCombie (2017) contended that East Asia grew as a result of the accumulation of many capabilities.

On the other end Rao and Owyong (1997) were of the opinion that as countries become more developed and move closer to the limits of factor accumulation, they turn to rely more and more on increasing productivity to sustain the economic growth process. Hsieh (1999) challenged key parts of Young's conclusions on productivity growth on some of the Asian economies such as Singapore which suggested that the rapid growth was supported almost entirely by physical and human capital accumulation. He argued that the analysis went wrong because of its reliance on Singapore's government national account statistics, which dramatically overstated the growth of the capital stock. Likewise, Hsieh also found that Taiwan's productivity growth was better than previously assessed by Young, but got less dramatic results for South Korea and Hong Kong. In addition, Nakamura et al., (2018) regard labour productivity as a source of medium to long term economic growth.

International Labour Organisation (ILO) (2013) indicated that the major decline in labour productivity growth occurred sharply in 2012 . It has been noted that at the global level, output per worker grew by only $1.9 \%$ in 2012, down from an average of $2.9 \%$ in the two previous years and below the pre-crisis average growth 
rate of $2.3 \%$. Similarly, Proudfoot (2008) showed that the percentage of a worker's time spent on unproductive activities rose 2.2 points in 2007 . The implication is that workers spend 89.5 days of every working year doing things which do not deliver productive results for their company. The same point was echoed by Nakamura et al., (2018) who suggested that labour productivity growth in major advanced countries has been experiencing a slowdown in recent years. They suggested that in Japan the decline is attributed to the inefficient use of technology and ideas accumulated by research and development and management of resources such as capital and labour. They also argue that these resources are not efficiently reallocated across corporations.

Despite these controversies, policymakers and economists around the globe are concerned about the declining levels of labour productivity because of its ability to limit potential for investment and real wage growth and also to harm aggregate demand. This concern is also true for South Africa which is faced with several challenges such as high levels of unemployment, higher wage bills and high levels of poverty. Out of a group of twelve countries, the SouthAfrican workers were found to have the greatest amount of unproductive time and they are said to be having one of the lowest employee productivity stats in the world (Proudfoot 2008). In line with the Proudfoot report, the ILO (2013) also recorded South Africa having one of the lowest employee productivity stats in the world. To demonstrate that the situation is still the same, of late, CEIC Data (2019) also revealed that labour productivity dropped by $1.13 \%$ year on year in December 2018 compared with a growth of $0.10 \%$ in the previous quarter.

The other challenge plaguing the South African economy is the ever-increasing demand for higher wages by the labour unions in almost all the sectors of the economy. This concern has also been taken up by the economic commentators and think-tanks. They have intervened in the debate about wages and protective labour laws with claims that the productivity of labour force is going down in the country. That been the case, it is recorded that in South Africa unskilled wage rates have rocketed about twice as quickly as in the rich world, after inflation, while management and specialised skills are often underpaid. In 2011 the average government salary was estimated at $34 \%$ higher than the private sector. Lower level civil servants, such as cleaners, earn more than teachers in India or Brazil. This may give reason why people cannot find work as the price of certain labour has become unaffordable. This is problematic because South Africa has the third highest unemployment rate in the world (IBN Business \& Immigration Solutions 2012). Moreover, South Africa's yearly minimum wage is set around $\$ 2,471.00$ and out of 68 countries with a higher minimum wage South Africa is in the top $35 \%$ of all countries based on the yearly minimum wage rate (https://www.minimum-wage.org/international/southafrica).

Regardless of the fact that there are concerns and challenges about the low levels of labour productivity, empirical evidences suggest that improving productivity is the key for sustainable economic growth. Onkelinx et al., (2016) argued that the benefits of improved productivity can also be felt at firm or industry levels. This is based on the perception that firms which invest in their employees through wages or training are more likely to have higher levels of labour productivity. They also indicated that it is critical for small internationalising firms as only the most productive firms can overcome the liability of smallness and foreignness and successfully compete in foreign markets. Similarly, Chang et al., (2016) concluded that if the percentage of university-educated employees in the city is increased by $1 \%$ plant productivity is increased by approximately $1.15 \%$.

Despite the perceived importance of the aspect of labour productivity in economic growth, this study could not find any evidence from the literature of any study done in this field in the South African context. Therefore, this study is envisaged to contribute to such a research gap. The study is also envisioned to provide an empirical evidence to policymakers and union leaders alike to begin to recognise more fully the importance of labour productivity towards economic growth. Therefore, purpose of this study is to investigate the implications of labour productivity and labour costs on the South African economy.

The rest of the paper is structured as follows: Section 2 focuses on the review of both the theoretical and the empirical literature related to the study. Section 3 deals with the model while section 4 is centred around the methodological aspects which cover data and model specification and the necessary econometric tests undertaken by the study. Section 5 focuses on the presentation of the empirical results and their discussion meanwhile Section 6 provides the conclusion and recommendations. 


\section{LITERATURE REVIEW}

Apart from previous theorists such as Solow (1957) the importance of labour productivity is also echoed by several modern theorists such as Klenow and Rodríguez-Clare (1997) and Easterly and Levine (2001) who through accounting exercise established that the bulk of economic growth comes from productivity. Easterly and Levine (2001) determined that growth is highly unstable over time, whereas factor accumulation is more stable. That being the case, they pointed that they did not deny that factor accumulation is critically important for some countries at specific junctures and at the same time, Total Factor Productivity (TFP) does not explain everything, everywhere and always. Rather, they were keen to show that something else besides factor accumulation plays a prominent role in explaining differences in economic performance across countries. Similarly, the same conception was echoed by Hall and Jones (1999)'s level accounting exercises which also specified that productivity is the key explanation for differences in the level of income among countries and over time.

As discussed in the introduction section, the empirical literature provides mixed results as far as the effect of productivity on economic performance is concerned. These differences steered different authors to challenge some of the economic growth theories and that led to some kind of an evolution of these theories. The argument seems to have been centred around the incorrect application of the TFP. Beyer and Vergara (2012) showed that several studies find that the unexplained part of output growth, the residuals or TFP is the most important element in explaining growth rate of different countries but they came to different conclusions. For instance, both Solow (1957) and Denison (1962) found very high rates of TFP for the United States and a group of European countries growth and such results triggered debate amongst several economists. It was discovered that they failed to recognise the heterogeneity of different inputs and the new estimates of TFP were calculated by categorising the inputs by type so that growth of capital and labour became a weighted average of the growth of the different input types.

The controversy is mainly centred around the NeoClassical model of Solow/Swan which suggested that increasing capital or labour leads to diminishing returns. The implication is that for the economy to grow there should be an increase in the gross domestic product (GDP) that is invested. This assertion is limited by the fact that the higher proportion of investment leads to diminishing returns and convergence on the steady-state of growth. The model also proposes that technological progress which increases productivity of capital/labour should also increase.

This led to a point where most of the empirical literature offered most of their support to the endogenous growth theory for a while. Later on, it was realised that the AK models have some weakness and this led to the revision of early endogenous models to formulate the augmented Solow model led by Mankiw et al., (1992). The newly formed model was reported to explain about $80 \%$ of the international variation in income per capita, and the estimated influences of physical capital accumulation, human capital accumulation, and population growth confirm the model's predictions (Mankiw, Romer, and Weil 1992). Still, Beyer and Vergara (2012) pointed out that the shortcomings of the augmented Solow model which indicates that steady state, the growth rate of per capita income is defined by the rate of technological change, which is exogenously determined and therefore unexplained led to the development of the Schumpeterian growth model of growth through destruction. According to Aghion and Howitt (1992), Schumpeter's process of creative destruction growth resulted exclusively from technological process, which in turn resulted from competition among research firms. Therefore, this model gained richness and realism if capital were introduced, either physical or human capital embodying technical change, or research and development capital that affect the arrival rate of innovations. Allowing unemployment by introducing research into the labour market, would facilitate study of the reciprocal interaction between technological change and the business cycle.

Finally, Hulten (2001) echoed that when the various assumptions are met, the residual is a valid measure of the shift in the production function and the positive value of the TFP residual greatly outweighs the negatives. For all its flaws, real and imagined, many researchers have used it to gain valuable insights into the process of economic growth. He reiterated that thousands of pages of research have been published, and more are added every year. An example of this argument is that the TFP residual is central to the recent debate over the role of computers in stimulating economic growth.

Another form of arguments about the effect of productivity and labour costs on economic performance 
was illustrated by some of the empirical studies such as Saulaja, et al., (2016) who posited that the sustainable operation and expansion of any enterprise is determined not only by the cost of labour but also by the quality and productivity of it. Their regression analysis coefficients showed that an increase in labour productivity by 1 EUR/h leads to an increase in labour costs by $1.12 \mathrm{EUR} / \mathrm{h}$. They found out that in order that enterprises in Latvia can increase their labour productivity, a higher value has to be added to products, particularly in manufacturing, and more innovations have to be introduced, particularly in the sector of information technologies.

Nakamura, et al., (2018) argued that in order to improve Japan's productivity in the medium to longterm, it is desirable to encourage the flexible reallocation of management resources such as capital and labour by changing working process at the corporate level in accordance with changes in the socio-economic environment and the advent of new technologies, as well as by improving efficiency in the labour and capital markets. Similarly, Mehra and Kaur (2018) suggested that in order to increase the productivity of labour, social security measures also need to be adopted in the economy and a special fund for workers should be created in the economy to pay lump-sum compensation to workers in the event of closure or downsizing of enterprise.

As note by several empirical studies, productivity of labour seems to be depend on many different issues. Ghate, et al., (2016) that the top ranked factors affecting labour productivity are labour supervision, skilled labour, scheduling of work, training of labour, payment, communication between site management and labour, etc. They argued that the skilled labour is a factor which highly affects the labour productivity; since with skilled labour work can be done in less time without compromising quality of work. The issue of skills or knowledge was also highlighted by Fu, et al., (2008) who tested the hypotheses using regional and firm level longitudinal data from China. They found that inequalities in knowledge creation and transfer, both inter-generational and international, played a significant role in increasing regional disparities in productivity. The inequalities were exacerbated by the accumulative nature of knowledge capital which can lead to selfperpetuating cycles of success and failure, particularly compounded with asymmetric financial and human capital between different regions.
As noted by Rizov and Zhang (2014) location is also a factor which influences productivity. They found that that regional productivity systematically differs across less sparse and sparse, coastal and inland, and highly urbanized, mixed and less urbanized, rural categories. Their findings are broadly consistent with the literature on regional income and output inequality, however, the magnitude of productivity disparities is smaller than the magnitudes exhibited by wages and output. Finally, Rizov and Zhang (2014) established that that in recent years there have been substantial improvements in productivity of inland and less urbanized, rural areas.

\section{THE MODEL AND DATA}

In line with Chang et al., (2016), Benos and Karagiannis (2016) and Owyong (1997) the proposed model is based on the production function but in order to investigate the implications of labour productivity and labour costs on the South African economy it focuses only on the output and labour aspects of the function. The study employed the quarterly time series data (1998Q1 to 2018Q2) from the South Africa Reserve Bank. In the model presented in Equation 1, labour productivity is proxied by labour productivity in the nonagricultural sectors and by labour productivity in manufacturing. Likewise, labour costs are proxied by unit labour costs in manufacturing and economic growth is proxied by the GDP at market prices. The model is presented as follows;

$$
\operatorname{InGDPMP}_{t}=\beta_{0}+\beta_{1} \text { LCMan }_{t}+\beta_{2} \text { LPNas }_{t}+\beta_{3} \text { LPMan }_{t}+\mu_{t} 1
$$

where

InGDPMp = Logarithm of GDP Market Prices;

LCMan = Labour costs in manufacturing

LPNas = Labour productivity in the non-agricultural sectors

LPMan = Labour productivity in manufacturing

\section{ECONOMETRIC METHODOLOGY}

The study employed Pesaran et al., (2001)'s Autoregressive Distributed Lag (ARDL) bounds test of cointegration approach to estimate the short and long run relationships among the variables. This technique was preferred because it has various econometric advantages that gained greater acceptance over the well-known residual-based approaches such as the Engle and Granger (1987) and Johansen and Juselius (1990). The Engle and Granger (1987) single equation 
cointegration approach suffers from problems of endogeneity while the ARDL model is able to distinguish between dependent and the explanatory variables. It also shows appropriate lags in the ARDL capture the data generating process in a general-tospecific modelling framework to correct for both residual correlation and endogeneity (Laurenceson and Chai 2003). According to Pradhan et al. (2013) the ARDL model also eliminates the need to use a large number of specifications required in other standard cointegration tests. These include decisions regarding the inclusion of the number of variables (both explained and explanatory), the treatment of deterministic elements and the choice of lag lengths among others. The ARDL bounds test of cointegration approach includes a preliminary unit root test, cointegration analysis and error correction model (ECM). Furthermore, to test the robustness of the model several diagnostic and stability tests were undertaken.

\subsection{Unit Root Test}

Since the econometric analysis of this study is based on time series data, it was necessary to perform a unit root analysis of each and every variable to determine the order of integration which is a prerequisite for almost all the time series analyses (Ajide 2014). This is based on the notion that generally; most empirical data is inconsistent with the null hypothesis that important macroeconomic series do not have a unit root (Nelson and Plosser 1982). Hence it was imperative to remove such trending behaviour to obtained valid results.

The other benefit is that the outcomes of the unit root test will help to select the appropriate econometric method for data analysis. Even though unit root testing is not a requirement for the ARDL approach, it is still necessary to conduct it to make sure that there is no variable(s) which is I(2) because according to Nkoro and Uko (2016) and Och, et al., (2017) its presence can lead to crashing of the Pesaran, et al., (2001)'s technique. The study employed the augmented DickeyFuller test statistic using a generalised least squares rationale unit root test known as Dickey-Fuller Generalized Least Squares (DF-GLS) by Elliott et al., (1996). Elliott et al., (1996) have shown that this test has a significantly greater power than the previous versions of the augmented Dickey-Fuller test and it is also an efficient test for an autoregressive unit root analysis. Furthermore, Zafeiriou and Azam (2017) emphasised the main objective of this particular test is to ensure that the time series employed are not I(2) a condition that implies robustness for the results derived by the ARDL bounds cointegration test. They explicitly noted that the absence of any I(2) or higher rank integrated series sets allows us to implement the ARDL bounds testing approach to cointegration.

\subsection{Long Run Relationship Analyses}

The presence of the long run relationship in Equation 1 will be determined by testing for the null hypothesis $\left(\mathrm{H}_{0}\right)$ of no cointegration. This will be achieved by imposing restrictions on the joint significance of parameters as $\mathrm{H}_{0}: \beta_{1}=\beta_{2}=\beta_{3}=\beta_{4}=0$ against the alternative hypothesis $\left(\mathrm{H}_{1}\right): \beta_{1} \neq 0, \beta_{2} \neq 0, \beta_{3}$ $\neq 0, \beta_{4} \neq 0$. The null hypothesis was tested by calculating the value of F-statistics and comparing it to the lower and the upper bounds critical values of Pesaran et al., (2001). The interpretation of the results will be based on Narayan (2005)'s view that if the Fstatistic is greater than the upper bound critical value at $5 \%$ level of significance then, the $\mathrm{H}_{0}$ is rejected which signifies the presence of a long-run relationship amongst the variables. On the other hand, if the $\mathrm{F}$ statistics is lower than the bound critical value, it will imply that there is no long run relationship and if it lies between the lower and the upper bounds of the critical values, the inference is inconclusive. To check for long run relationship among the variables the following ARDL model was adopted;

$$
\begin{aligned}
& \Delta \operatorname{InGDPMp}_{t}=\beta_{0}+\sum_{i=1}^{m} \beta_{1} \Delta \operatorname{InGDPMp}_{t-i}+\sum_{i=1}^{m} \beta_{2} \Delta \text { LCMan }_{t-1} \\
& +\sum_{i=1}^{m} \beta_{3} \Delta \text { LPNas }_{t-i}+\sum_{i=1}^{m} \beta_{4} \Delta \text { LPMan }_{t-i}+\alpha_{1} L \text { GDPMp } \\
& +\alpha_{t-1} \\
& +\alpha_{2} \text { Man }_{t-1}+\alpha_{3} \text { LPNas }_{t-1}+\alpha_{4} \text { LPMan }_{t-1}+\mu_{t-1}
\end{aligned}
$$

where $\Delta$ is the difference operator; $\beta_{1}$ to $\beta_{4}$ are the long run parameters (elasticity's) and the parameters $\alpha_{1}$ to $\alpha_{4}$, are the short run dynamic coefficients of the ARDL model.

\subsection{Short Run Relationship Analyses}

Furthermore, the ARDL model was reparameterised into an error correction model (ECM) through a simple linear re-parameterisation as presented in Equation 3. This is made possible by the fact that ARDL is a dynamic single model equation and of the same form with the ECM. The re-parameterised result will provide the short run dynamics and it is presented as follows; 
Table 1: DFGLS Unit Root Test Results

\begin{tabular}{|c|c|c|c|c|c|}
\hline Variables & Model & Lag-length & t-statistics & P-value & Order of integration \\
\hline $\operatorname{InGDPMp}$ & \multirow{4}{*}{ 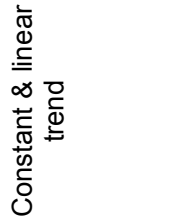 } & 0 & -4.994579 & 0.0000 & $\mathrm{I}(1)$ \\
\hline LPNas & & 0 & -9.417958 & 0.0000 & $\mathrm{I}(1)$ \\
\hline LCMan & & 0 & 0.0000 & 0.0000 & $\mathrm{I}(1)$ \\
\hline LPMan & & 0 & -7.861968 & 0.0000 & $\mathrm{I}(0)$ \\
\hline
\end{tabular}

$\Delta \operatorname{InGDPMp_{t}}=\beta_{0}+\sum_{i=1}^{m} \beta_{1} \Delta \operatorname{InGDPMp_{t-i}}+\sum_{i=1}^{m} \beta_{2} \Delta L C M a n_{t-1}$

$+\sum_{i=1}^{m} \beta_{3} \Delta \operatorname{LPNas}_{t-i}+\sum_{i=1}^{m} \beta_{4} \Delta L P \operatorname{Man}_{t-i}+\beta_{5} E C T_{t-i}+\mu_{t}$

where $\Delta$ is the first difference operator; $\beta_{1}$ to $\beta_{4}$ capture the short run dynamics of the model; $\mu_{t}$ is the error term assumed to be uncorrelated and $E C T_{t-i}$ is the error correction term obtained from the equation. $\beta_{5}$ as the coefficient of the ECT is expected to be negative and it will help to capture the adjustment towards long run equilibrium.

\subsection{Diagnostic and Stability Tests}

Finally, to make the ARDL results more robust, the model will be taken through a battery of both diagnostic and stability tests. The diagnostic tests included normality test, serial correlation test and heteroscedasticity test. On the other hand, the stability tests include the cumulative sum (CUSUM) and the cumulative sum of squares (CUSUMSQ). According to Alabdulrazag and Alrajhi (2016), it is more likely that macroeconomic series may experience one or multiple structural breaks due to the structural changes in developing economies. Therefore, it is imperative to check for the stability of the short run and long run coefficients.

\section{EMPIRICAL RESULTS AND DISCUSSION}

This section presents the results and analyses of all the estimation techniques performed in this study. This includes discussions of the unit root tests, ARDL bounds test of cointegration approach, both the long and the short run analyses and the diagnostic and stability tests.

\subsection{Unit Root/Stationarity}

As illustrated in Table 1, the best outcome of the unit root test was obtained when applying the constant and linear trend and the results confirm that all the variables became stationary after first difference except labour productivity in manufacturing which was found to be stationary at level. The implication is that since there is a mixture of both $\mathrm{I}(0)$ and $\mathrm{I}(1)$ variables and also the fact that there is no I(2) variable in the system the application of the ARDL model became the relevant choice approach for this study.

\subsection{Cointegration Analysis Results}

The cointegration analysis results in Table $\mathbf{2}$ show that the F-statistic (12.9758) is greater than the Narayan (2005) and Pesaran et al., (2001) critical values, that is, both the upper critical values I (1) and lower critical I (0) values at $10 \%, 5 \%$ and $1 \%$ significant levels hence the null hypothesis of no cointegration was not accepted. This implies that the presence of cointegration has been established therefore there is a long run relationship amongst labour productivity, labour costs and economic growth.

Table 2: ARDL Bounds Test Results

\begin{tabular}{|c|c|c|}
\hline Test statistic & Value & K \\
\hline \hline F-Statistics & 12.9758 & 3 \\
\hline \multicolumn{3}{|c|}{ Critical value bounds } \\
\hline Significance levels & I(0) Bound & I(1) Bound \\
\hline $10 \%$ & 2.72 & 3.77 \\
\hline $5 \%$ & 3.23 & 4.35 \\
\hline $2.5 \%$ & 3.69 & 4.89 \\
\hline $1 \%$ & 4.29 & 5.61 \\
\hline
\end{tabular}

Since cointegration has been established in the system, the long run analysis was undertaken and the estimation results are presented in Table 3 below.

\subsubsection{Long Run Relationship Analyses}

From the long run estimation elasticities in Table 3 it was established that both labour productivity in the non-agricultural sectors and labour productivity in manufacturing have a significant positive impact on 
Table 3: Estimated Long Run Results

\begin{tabular}{|c|c|c|c|c|}
\hline Variable & Coefficient & Std. Error & t-statistics & p-value \\
\hline \hline LCMan & -4978.813674 & 2174.711369 & -2.289414 & 0.0249 \\
\hline LPNas & 13704.538023 & 6614.634029 & 2.071851 & 0.0418 \\
\hline LPMan & 32376.8282 & 6520.604509 & 4.965311 & 0.0000 \\
\hline
\end{tabular}

economic growth however labour costs in manufacturing has a significant negative impact on the South African economy.

The final step of the ARDL model was the estimation of the error correction for estimating the short run parameters and the speed of adjustment of the system. The results are presented in Table 4.

\subsubsection{Short Run Relationship Analysis}

The results in Table 4 show that the coefficient of the ECT $(-0.08)$ indicates that a $1 \%$ increase in random shocks to equilibrium will lead to $0.8 \%$ amendment in the equilibrium. Since cointegration has been established, this means that any change in the current equilibrium level of the economy is a temporary phenomenon and will come to the long run path in future. Based on the outcome of this result it means that any deviation of the equilibrium will be corrected at the speed of $0.8 \%$ quarterly from short run to the long run.

Furthermore, the short run analysis results show that the rest of the specified variables are significant, which implies that there is an effect of the specified variables namely, labour costs in manufacturing, labour productivity in the non-agricultural sectors and labour productivity in manufacturing on GDP at market prices in the short-run.

\subsection{Diagnostic and Stability Tests Results}

Table 5 presents a summary of all the diagnostic tests while the outcomes of the stability tests are presented in Figures 1 and 2 respectively.

The summary of the outcome of the diagnostic tests in Table 5 indicates that the study could not reject the null hypothesis of the three diagnostic tests because their $p$-values are greater than 5\% ( $p>0.05)$. The findings show that the model has passed the tests for autocorrelation and heteroskedasticity and that the residuals are normally distributed since all the null hypotheses could not be rejected. These results support the results of the ARDL model.

The coefficients using CUSUM and CUSUMSQ tests in Figures 1 and 2 clearly show that they do not exceed critical values. According to Brown et al., (1975), these findings show that there is parameter stability because the lines generated are within the upper bound and lower bound lines of $5 \%$ significance level. This confirms that the model has been stable throughout the period of study.

Table 4: Estimated Short Run Analysis Results

\begin{tabular}{|c|c|c|c|c|}
\hline Variable & Coefficient & Std. Error & t-statistics & p-value \\
\hline \hline$D($ LCMan $)$ & -2044.959487 & 691.541325 & -2.957104 & 0.0042 \\
\hline$D($ LPNas $)$ & 8755.664520 & 1561.877166 & 5.605860 & 0.0000 \\
\hline$D($ LPMan $)$ & 2688.849060 & 531.802979 & 5.056100 & 0.0000 \\
\hline Coint $E q(-1)$ & -0.083049 & 0.020703 & -4.011397 & 0.0001 \\
\hline
\end{tabular}

Table 5: Summary of Diagnostic

\begin{tabular}{|c|c|c|c|}
\hline Diagnostic analysis & Test & p-value & Conclusion \\
\hline \hline Serial correlation & Breusch-Godfrey LM test & 0.1739 & Do not reject null \\
\hline Heteroskedasticity & White test & 0.9312 & Do not reject null \\
\hline Normality & Jarque-Bera & 0.1349 & Do not reject null \\
\hline
\end{tabular}




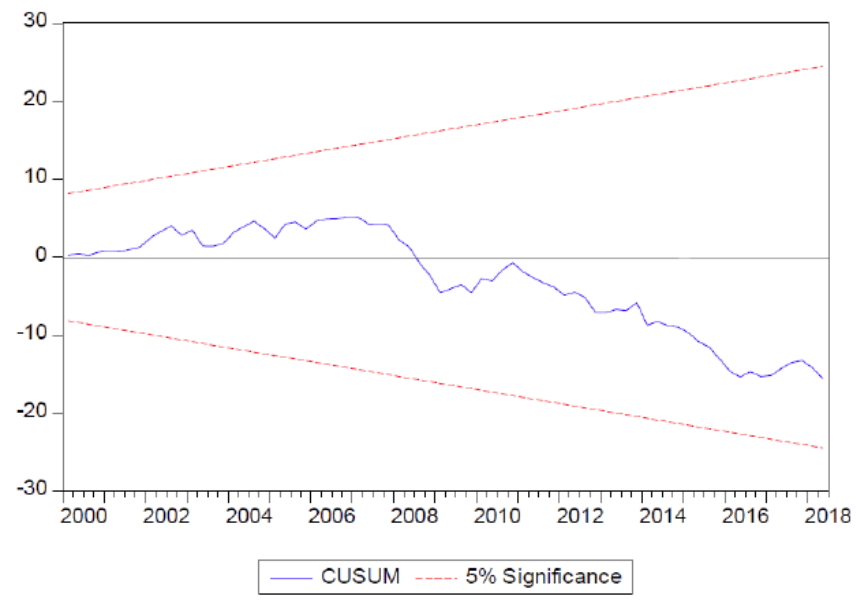

Figure 1: CUSUM.

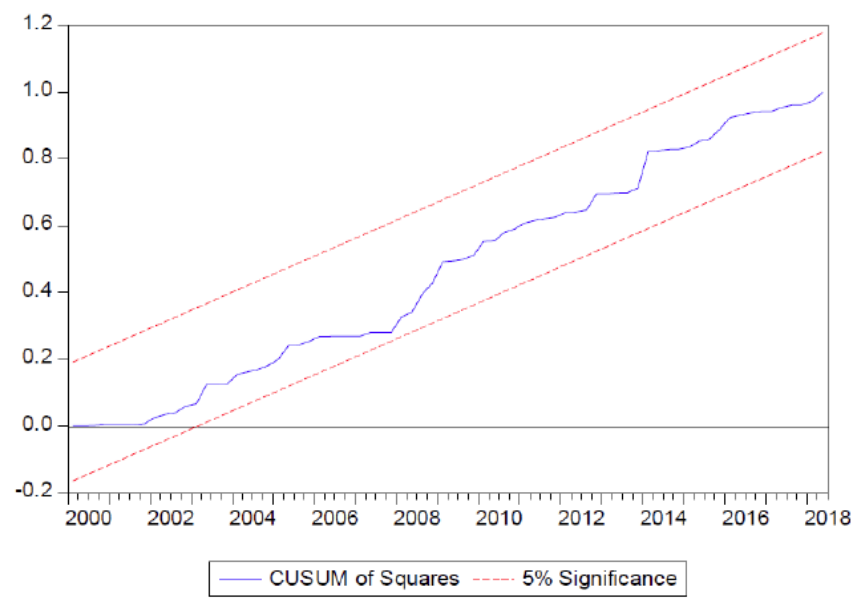

Figure 2: CUSUM of Squares.

\section{CONCLUDING REMARKS}

The purpose of this study was to econometrically investigate the implications of labour productivity and labour costs on the South African economy by using ARDL approach. The study provided an empirical evidence to policymakers and union leaders alike to begin to recognise more fully the importance of these indicators in the South African case.

The overall conclusion is that labour productivity has a significant positive impact on economic growth while labour costs have a negative impact on the case of South Africa. This was based on the fact that the two proxies of labour productivity in the form of labour productivity in the non-agricultural sectors and labour productivity in manufacturing have significant positive coefficients which means positive effects on economic growth. On the other hand, the coefficient of labour costs in manufacturing was negative hence, negative effects on economic growth. The inference is that labour productivity leads to the promotion of growth in the South African context in the long run meanwhile the ever increasing labour costs have negative effects. The presence of the long run association in the system was confirmed by short analysis which proved that any change in the current equilibrium level of the economy is a temporary phenomenon which will be brought to the long run path in future.

The importance of labour productivity in the South African economy is in line with earlier studies such as Klenow and Rodríguez-Clare (1997) and Easterly and Levine (2001). The results are also in tandem with Onkelinx et al., (2016) who stated that investments in employee human capital are critical for the labour productivity. South Africa should formulate policies that can help to improve the quality of its labour force or human capital in order to achieve desired economic growth that can help to increase the levels of employment and the reduction of poverty. Similarly, the negative effects of the labour costs on economic growth should send a signal to both the workers and the labour unions to be cautious not to milk the cash cow until it dies.

\section{REFERENCES}

Aghion, Philippe, and Peter Howitt. 1992. 'A Model of Growth Through Creative Destruction'. Econometrica 60(2): 323-51. https://doi.org/10.2307/2951599

Ajide, Kazeem B. 2014. 'Determinants of Economic Growth in Nigeria'. Cbn Journal Of Applied Statistics Vol. 5. http://www.academix.ng/search/paper.html?idd=3300013990 (May 6, 2019).

Alabdulrazag, Bashier, and Ahmed Alrajhi. 2016. 'The Validity of Environmental Kuznets Curve Hypothesis in the Kingdom of Saudi Arabia: ARDL Bounds Testing Approach to Cointegration'. International Review of Management and Business Research 5(4): 1450-64. www.irmbrjournal.com (November 1, 2018).

Benos, Nikos, and Stelios Karagiannis. 2016. 'Do Education Quality and Spillovers Matter? Evidence on Human Capital and Productivity in Greece'. Economic Modelling 54(2016): 56373.

https://doi.org/10.1016/j.econmod.2016.01.015

Beyer, Harald, and Rodrigo Vergara. 2012. 21501 Productivity and Economic Growth: The Case of Chile. Santiago.

Brown RL., Durbin J., Evans, J.M. 1975. 'Techniques for Testing the Constancy of Regression Relationships over Time'. Journal of the Royal Statisiticaal Society 37(2): 149-92. https://doi.org/10.1111/j.2517-6161.1975.tb01532.x

CEICData. 2019. 'South Africa Labour Productivity Growth [2009 2018]'. CEIC Data. https://www.ceicdata.com/en/indicator/ south-africa/labour-productivity-growth (May 6, 2019).

Chang, Ching-fu, Ping Wang, and Jin-tan Liu. 2016. 'Knowledge Spillovers, Human Capital and Productivity'. Journal of Macroeconomics 47(2016): 214-32. https://doi.org/10.1016/j.jmacro.2015.11.003

Denison, EF. 1962. 'The Sources of Economic Growth in the United States and the Alternatives before Us'. 
Easterly, William, and Ross Levine. 2001. 'It 's Not Factor Accumulation: Stylized Facts and Growth Models'. The World Bank Economic Review 15(2): 177-219. https://doi.org/10.1093/wber/15.2.177

Elliott, Graham et al. 1996. 'Efficient Tests for an Autoregressive Unit Root'. Econometrica 64(4): 813. https://doi.org/10.2307/2171846

Engle, Robert F., and C. W. J. Granger. 1987. 'Co-Integration and Error Correction: Representation, Estimation, and Testing'. Econometrica 55(2): 251 https://doi.org/10.2307/1913236

Felipe, Jesus, and John McCombie. 2017. The Debate about the Sources of Growth in East Asia after a Quarter of a Century: Much Ado about Nothing. Mandaluyong City. https://doi.org/10.22617/WPS178815-2

Fu, Xiaolan, Shujin Zhu, and Yundan Gong. 2008. Knowledge Capital, Endogenous Growth and Regional Disparities in Productivity: Multi-Level Evidences from China. https://www.researchgate.net/publication/277790370 (March 2, 2019).

Ghate, Prachi R., Ashok B. More, and Pravin R. Minde. 2016. Importance of Measurement of Labour Productivity in Construction'. International Research Journal of Engineering and Technology (IRJET) 05(07): 413-17. https://doi.org/10.15623/ijret.2016.0507065

Hall, Robert E, and Charles Jones. 1999. 'Why Do Some Countries Produce So Much More Output Per Worker Than Others?' Quarterly Journal of Economics 114(February): 83-116. https://doi.org/10.1162/003355399555954

Hsieh, Chang-Tai. 1999. 'Productivity Growth and Factor Prices in East Asia'. American Economic Review 89(2): 133-38. https://doi.org/10.1257/aer.89.2.133

Hulten, Charles R. 2001. 'New Developments in Productivity Analysis'. In Economic Systems Research, ed. Edwin R. Dean and Michael J. Harper Charles R. Hulten. Chicago: University of Chicago Press, 1-54.

IBN Business \& Immigration Solutions. 2012. 'Employee Productivity in South-Africa's War for Wages'. IBN Immigration and Business Solutions. https://ibn.co.za/employee-productivityin-south-africas-war-for-wages/ (January 10, 2019).

ILO. 2013. Global Employment Trends 2013: Recovering from a Second Jobs Dip. Geneva: International Labour Office. www.ilo.org/publns (January 10, 2019).

Johansen, Søren, and Katarina Juselius. 1990. 'Maximum Likelihood Estimation and Inference on Co-Integration'. Oxford Bulletin of Economics and statistics 52(2): 169-210. https://doi.org/10.1111/j.1468-0084.1990.mp52002003.x

Klenow, Peter, and Andrés Rodríguez-Clare. 1997. 'The Neoclassical Revival in Growth Economics: Has It Gone Too Far?' NBER Chapters: 73-114. https://doi.org/10.2307/3585220

Krugman, Paul. 1994. 'The Myth of Asia's Miracle'. Foreign Affairs 73(6): 62-78. https://www.jstor.org/stable/pdf/20046929.pdf? refreqid=excelsior\%3Af6a843b43cf6fb456010474c541de618 (March 2, 2019).

Laurenceson, James, and Joseph CH Chai. 2003. Financial Reform and Economic Development in China. Edward Elgar Publishing. https://doi.org/10.4337/9781843767190

Mankiw, N. Gregory, David Romer, and David N. Weil. 1992. "'A Contribution to the Empirics of Economic Growth."' The quarterly journal of economics 107.2(1992): 407-37. https://doi.org/10.2307/2118477

Mehra, Anjali, and Pardeep Kaur. 2018. 'Drivers of Labour Productivity: Evidence from Manufacturing Sector'. Pacific Business Review International 10(11): 45-51. www.pbr.co.in (January 13, 2019).
Nakamura, Koji, Sohei Kaihatsu, and Tomoyuki Yagi. 2018. 'Productivity Improvement and Economic Growth: Lessons from Japan'. Economic Analysis and Policy. https://linkinghub.elsevier.com/retrieve/pii/S03135926183017 59 (January 10, 2019).

Narayan, Paresh Kumar. 2005. 'The Saving and Investment Nexus for China: Evidence from Cointegration Tests'. Applied Economics 37(17): 1979-90. https://doi.org/10.1080/00036840500278103

Nelson, Charles R, and Charles I Plosser. 1982. 'Trends and Random Walks in Macroeconomic Time Series: Some Evidence and Implications'. Journal of Monetary Economics 10(I 982): 139-62. https://doi.org/10.1016/0304-3932(82)90012-5

Nkoro, Emeka, and Aham Kelvin Uko. 2016. 'Autoregressive Distributed Lag (ARDL) Cointegration Technique: Application and Interpretation'. Journal of Statistical and Econometric Methods 5(4): 63-91. http://www.scienpress.com/ Upload/JSEM/Vol 5_4_3.pdf (November 1, 2018).

Och, Maralgua, Christian Baerbig, and Tsolmon Jadamba. 2017. 'Determinants of Inward FDI in Mongolia: An Application of the ARDL Bounds Testing Approach to Cointegration'. Asian Economic and Financial Review 7(3): 307-33.

https://doi.org/10.18488/journal.aefr/2017.7.3/102.3.307.333

Onkelinx, Jonas, Tatiana S Manolova, and Linda F Edelman. 2016. 'The Human Factor: Investments in Employee Human Capital , Productivity, and SME Internationalization'. Journal of International Management 22(2016): 351-64. https://doi.org/10.1016/j.intman.2016.05.002

Owyong, David T. 1997. 'Productivity Growth: Theory and Measurement'. APO Productivity Journal: 19-29.

Pesaran, M. Hashem, Yongcheol Shin, and Richard J. Smith. 2001. 'Bounds Testing Approaches to the Analysis of Level Relationships'. Journal of Applied Econometrics 16(3): 289326. https://doi.org/10.1002/jae.616

Pradhan, Rudra P., Neville R. Norman, Yuosre Badir, and Bele Samadhan. 2013. 'Transport Infrastructure, Foreign Direct Investment and Economic Growth Interactions in India: The ARDL Bounds Testing Approach'. In Procedia - Social and Behavioral Sciences, Elsevier, 914-21. https://doi.org/10.1016/j.sbspro.2013.11.186

Proudfoot. 2008. Global Productivity Report: A World of Unrealised Opportunities 2008.

Rao, Bhanoji, and David Owyong. 1997. "Sources of Growth in the Singapore Economy: Some New Results."' In International Conference on Efficiency and Productivity Growth, Taipei: Academia Sinica.

Rizov, Marian, and Xufei Zhang. 2014. 'Regional Disparities and Productivity in China: Evidence from Manufacturing Micro Data'. Papers in Regional Science 93(2): 321-39. https://doi.org/10.1111/pirs.12051

Saulaja, Inese, Anda Zvaigzne, and Iveta Mietule. 2016. 'Labour Costs and Productivity in Latvia'. In ECONOMIC SCIENCE FOR RURAL DEVELOPMENT, 150-56. http://lufb.Ilu.Iv/ conference/economic science rural/2016/Latvia ESRD 42 2016-150-156.pdf (May 6, 2019)

Solow, Robert M. 1957. 'Technical Change and the Aggregate Production Function'. The Review of Economics and Statistics 39(3): 312-20. https://doi.org/10.2307/1926047

Totaro, Lorenzo. 2019. 'Italy, Failing on Debt Reduction, Is a Risk for Europe, EU Warns'. Bloomberg. https://finance.yahoo.com/ news/italy-failing-debt-reduction-risk-110756254.html (February 27, 2019) 
Young, Alwyn. 1995. 'Tyranny of Numbers: Confronting the Statistical Realities of the East Asian Growth Experience'. The Quarterly Journal of Economics 110(3): 641-80. https://doi.org/10.2307/2946695
Zafeiriou, Eleni, and Muhammad Azam. 2017. 'CO2 Emissions and Economic Performance in EU Agriculture: Some Evidence from Mediterranean Countries'. Ecological Indicators 81: 104-14.

https://doi.org/10.1016/j.ecolind.2017.05.039

DOI: https://doi.org/10.6000/1929-7092.2019.08.113

(C) 2019 Itumeleng Pleasure Mongale; Licensee Lifescience Global.

This is an open access article licensed under the terms of the Creative Commons Attribution Non-Commercial License (http://creativecommons.org/licenses/by-nc/3.0/) which permits unrestricted, non-commercial use, distribution and reproduction in any medium, provided the work is properly cited. 